\title{
Alergija vabzdžių nuodams: diagnostika, skubioji pagalba ir ilgalaikè imunoterapija
}

\author{
Edita Gasiūnienè, Jūratė Staikūnienė \\ LSMU MA Pulmonologijos ir imunologijos klinika
}

Reikšminiai žodžiai: vabzdžių igèlimas, Hymenoptera, anafilaksija, specifinè imunoterapija.

Santrauka. Dažniausiai alergiją sukelia bičių ir vapsvų nuodai. Vabzdžių igèlimo sukeltos reakcijos gali būti vietinės ir sisteminès. Paprastai vabzdžiu igèlimas pasireiškia dilgèline, angioedema, anafilaksija. Alergija vapsvų ir bičių nuodams yra grindžiama anamneze, klinikiniais požymiais, teigiamais odos dūrio méginiais bei specifinio lgE prieš nuodų alergenus kraujyje nustatymu. Specifinè imunoterapija vabzdžių alergenams tęsiama trejus-penkerius metus.

Kodèl alergijos vabzdžiams problema yra aktuali? Todèl, kad nuo vabzdžio igèlimo sukeltos alerginès reakcijos ne vienas žmogus yra miręs, kitiems dèl išplitusių reakcijų prireikia gydytis stacionare. Literatūros duomenimis, JAV 0,4-0,8 proc. vaikų ir 3 proc. suaugusiųjų jautrumas vabzdžių įkandimams yra padidèjęs [1]. 30-50 amerikiečių kasmet miršta nuo sisteminių reakcijų, dažniausiai anafilaksinio šoko po vabzdžio igèlimo. Europos šalyse 0,8-5 proc. gyventojų yra patyrę išplitusią alerginę reakciją igèlus vabzdžiui [2]. Alergija vabzdžių nuodams gali pasireikšti ne tik alerginèmis ligomis sergantiems žmonèms, bet ir tiems, kurie anksčiau neturèjo jokių alergi-

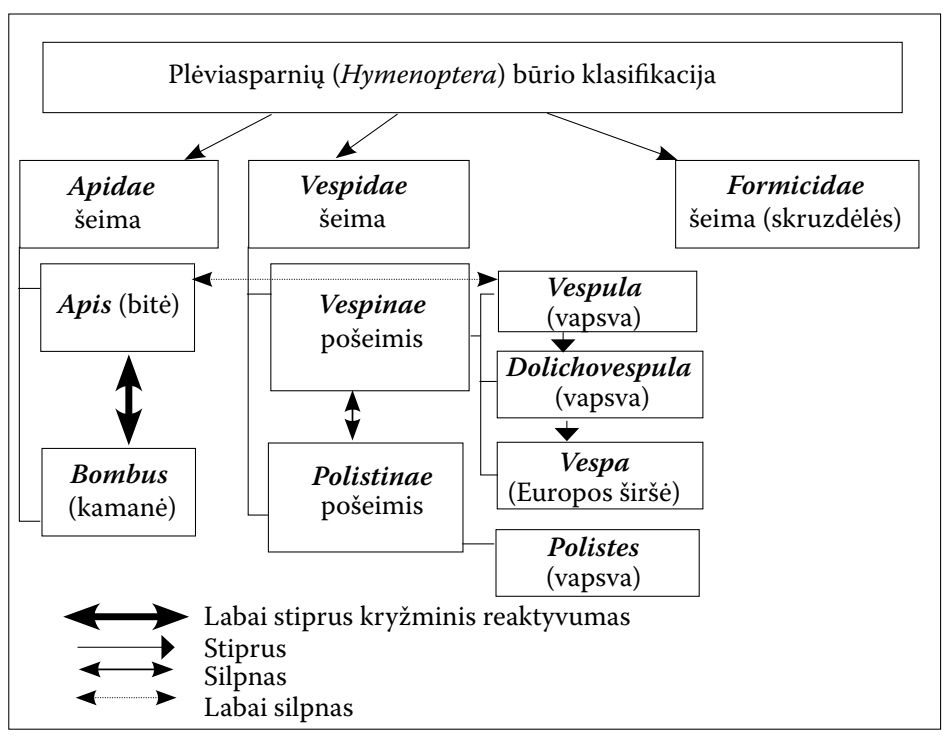

1 pav. Plèviasparnių būrio klasifikacija jos simptomų. Igėlęs vabzdys, išskiria ị žmogaus audinius baltyminès kilmès sekretą su alergenais, t. y. fermentais hialuronidaze, fosfolipaze A ir B, histaminu, lizofosfolipaze, nuodais, sukeliančiais lygiụjų raumenų spazmą.

\section{PLÉVIASPARNIŲ BŪRIO VABZDŽIAI}

Alergines reakcijas sukelia plèviasparnių būrio (Hymenoptera) vabzdžiai, kurie klasifikuojami ị Apidae ir Vespidae šeimas. Apidae šeimos vabzdžiai yra stambios, labai plaukuotos bendruomeninès bitès su ilgu straubleliu ir kamanès. Ju kūno spalva ịvairi, kiekviena rūšis turi daug spalvinių formų. Lietuvoje žinomos 23 kamanių rūšys, iš jų trys ịrašytos ì Lietuvos raudonąją knygą. Vespidae šeimos vabzdžiai beveik neturi plaukelių, o turi juodos ir geltonos spalvos dryžius pilvo srityje. Ši šeima skiriama ì Vespinae ir Polistinae pošeimius, turinčius skirtingą krūtinès ir pilvo jungtị. Plèviasparnių būrio klasifikacija pateikta 1 paveiksle.

Alergiją dažniausiai sukelia bitès (Apis mellifera) ir vapsvos (Vespula germanica, V. vulgaris), retai kitos vapsvos ir širšès, dar rečiau kamanès [3].

\section{ALERGIJOS VABZDŽIAMS DIAGNOSTIKA}

Igèlus vabzdžiui, būtina išsiaiškinti, kokios rūšies vabzdys buvo, atkreipiant dèmesi $\mathfrak{i}$ dydị, išvaizdą ar igèlimo vietoje nepaliko geluonies. Alergija Hymenoptera vabzdžiams nustatoma pagal klinikinius požymius ir diagnostinių tyrimų duomenis.

Vabzdžių igèlimo sukeltos reakcijos gali būti vietinès ir sisteminès. Jei igèlimas nealergiškiems žmonèms 
sukelia skausmą, paraudimą, nežymų paraudimą, patinimą bei išsilaiko mažiau nei parą, tai normali vietinè reakcija ị vabzdžio ịkandimą. Tačiau, jei igėlimo vietoje patinimas didesnis nei $10 \mathrm{~cm}$, išlieka ilgiau nei dvi paras, žmogui sukelia diskomfortą ar netgi patinimus akių, lūpų srityje, silpnumą, karščiavimą, galvos skausmą - tai yra stipri vietinè reakcija.

Dažniausiai anafilaksiją sąlygoja E klasès imunoglobulinai (IgE) prieš nuodų alergenus, rečiau $G$ klasės (IgG). Jos eigos sunkumas klasifikuojamas pagal Müller (1 lentelè) [3]. Diagnostika turi būti labai greita, ypač kai paciento būklè darosi nestabili.

Kartais kyla sisteminè toksinė reakcija dèl didesnès nuodų dozès, kai ịkanda daugiau nei 50 vabzdžių. Nuodų komponentai hialuronidazè ir fosfolipazė pažeidžia miokardą, kepenis, krešejimo sistemą, sukelia diseminuotą intravazalinę koaguliaciją.

Alergijos vabzdžiams neužtenka patvirtinti vien klinikiniais simptomais. Pacientai yra siunčiami pas gydytojus alergologus-imunologus atlikti specifinių tyrimų, kurie patvirtina alergiją vabzdžiams. Atliekami odos dūrio mėginiai, patvirtinantys IgE mechanizmą, arba nuodams specifinių IgE serume tyrimas [4]. Tyrimai atliekami ne anksčiau kaip dvi savaitès po alerginès reakcijos. Literatūros duomenimis, 20-50 proc. pacientų nustatomi teigiami titrai IgE antikūnuc ir prieš bitès, ir prieš vapsvos nuodų alergenus. Tuo atveju tenka nustatyti, ar žmogus įsijautrinęs abiejų vabzdžių nuodų alergenams, ir reikia taikyti specifinę imunoterapiją abiejų vabzdžių nuodų alergenų vakcina, arba teigiamas rezultatas yra dèl kryžminès antikūnų reakcijos i panašius alergenus, ir pakanka gydyti tik vieno alergiją sukèlusio vabzdžio nuodụ alergenụ vakcina. Isijautrinimą abiejų vabzdžių nuodų alergenams galima nustatyti naudojant rekombinantinius didžiuosius rūšinius bitès alergenus Api $\mathrm{m} 1$ ir vapsvos Ves v 5, nes 97 proc. bitès nuodams alergiškų žmonių turi antikūnų prieš bendrus bitès ir rekombinantini Api m1 alergeną, 96 proc. alergiškų vapsvos nuodams žmonių turi antikūnų prieš bendrus vapsvos ir rekombinantini Ves v 5 alergeną [5]. Jei nustatoma sIgE ir prieš Api m1, ir prieš Ves v5, patvirtinamas įsijautrinimas abiejų vabzdžių nuodams [5].

Odos dūrio méginiai atliekami su atskiestu vabzdžių nuoduc alergeno (VNA) tirpalu, pradinè koncentracija $0,01 \mu \mathrm{g} / \mathrm{ml}$. Vertinama po 15 minučiuc, jei susidariusi papule $\geq 3 \mathrm{~mm}$, méginys yra teigiamas. Jei mejginys neigiamas, atliekama su 0,1, 1; 10 ir $100 \mu \mathrm{g} / \mathrm{ml}$ koncentracijos VNA tirpalais. Jei dūrio mėginys neigiamas, atliekamas íodinis méginys, suleidžiama ị odą dilbio srityje $0,02 \mathrm{ml}$ $0,001 \mu \mathrm{g} / \mathrm{ml}$ VNA tirpalo. Vertinama po 15 minučių, jei papule $\geq 5 \mathrm{~mm}$, yra eritema, méginys teigiamas. Jei mèginys neigiamas, atliekama su 0,$01 ; 0,1$ ir $1 \mu \mathrm{g} / \mathrm{ml}$ koncentracijos tirpalu. Jei odos méginiai neigiami, o alerginè reakcija buvo sunkios eigos, pakartotinis méginių ir sIgE tyrimas atliekamas po 1-2 ménesių.

\section{PIRMOJI PAGALBA İYKUS SISTEMINEI ANAFILAKSINEI REAKCIJAI}

Vietinès ar lengvos alerginès reakcijos atveju svarbu nedelsiant pašalinti bitès geluoni, jo nespaudžiant, bet nubraukiant pincetu, netraumuojant pažeistos vietos, kad greitai neplistų ì kraujotaką patekę nuodai. Esant stipriai vietinei reakcijai, reikia uždèti šaltą kompresą, tepti gliukokortikoidu tepalu, vartoti geriamųu $\mathrm{H} 1$ an-
1 lentelè. Sisteminès alerginès reakcijos, igèlus vabzdžiui, sunkumas pagal Müeller

\begin{tabular}{|c|c|c|c|}
\hline $\begin{array}{l}\text { Reakcijos } \\
\text { sunkumo } \\
\text { laipsnis }\end{array}$ & \multicolumn{3}{|l|}{ Požymiai } \\
\hline 1 & \multicolumn{3}{|c|}{ Išplitusi dilgèlinè, niežèjimas, silpnumas, nerimas } \\
\hline 2 & \multicolumn{3}{|c|}{$\begin{array}{l}\text { Vienas iš jų bei } 2 \text { ir daugiau: angioedema, spaudimas } \\
\text { krūtinèje, pykinimas, vėmimas, diarèja, pilvo skaus- } \\
\text { mas, svaigimas }\end{array}$} \\
\hline 3 & \multicolumn{3}{|c|}{$\begin{array}{l}\text { Vienas iš jų bei } 2 \text { ir daugiau: dusulys, švokštimas, } \\
\text { stridoras, dizartrija, balso užkimimas, silpnumas, } \\
\text { sumišimas, mirties ir grèsmės baimé }\end{array}$} \\
\hline 4 & \multicolumn{3}{|c|}{$\begin{array}{l}\text { Vienas iš jų bei } 2 \text { ir daugiau: kraujospūdžio mažè- } \\
\text { jimas, kolapsas, sąmonès praradimas, nevalingas } \\
\text { šlapinimasis, tuštinimasis, cianozè }\end{array}$} \\
\hline \multicolumn{4}{|c|}{2 lentelè. Indikacijos atlikti SIT vabzdžių nuodų alergenais } \\
\hline \multicolumn{2}{|c|}{ Reakcijos tipas } & $\begin{array}{l}\text { Diagnostiniai } \\
\text { tyrimai } \\
\text { (odos mėginiai, } \\
\text { ir/ar sIgE) }\end{array}$ & $\begin{array}{l}\text { SIT } \\
\text { taikymas }\end{array}$ \\
\hline \multicolumn{2}{|c|}{$\begin{array}{l}\text { Kvėpavimo bei širdies ir krauja- } \\
\text { gyslių sistemų simptomai }\end{array}$} & $\begin{array}{l}\text { Teigiami } \\
\text { Neigiami }\end{array}$ & $\begin{array}{l}\text { Taip } \\
\mathrm{Ne}\end{array}$ \\
\hline \multicolumn{2}{|c|}{$\begin{array}{l}\text { Dilgèlinè, angioedema (jei yra } \\
\text { didelè igèlimo rizika, širdies li- } \\
\text { gos, mastocitozè, psichologiniai } \\
\text { veiksniai, nerimas, pablogèjusi } \\
\text { gyvenimo kokybè) }\end{array}$} & Teigiami & Taip \\
\hline \multicolumn{2}{|c|}{$\begin{array}{l}\text { Vietinè alerginè reakcija (edema } \\
>10 \mathrm{~cm} \text {, trukmé }>24 \text { val.) }\end{array}$} & $\begin{array}{l}\text { Teigiami ar } \\
\text { neigiami }\end{array}$ & $\mathrm{Ne}$ \\
\hline \multicolumn{2}{|c|}{$\begin{array}{l}\text { Neiprastos (vaskulitas, nefrozė, } \\
\text { karščiavimas, trombocitopenija } \\
\text { ir kt.) }\end{array}$} & $\begin{array}{l}\text { Teigiami ar } \\
\text { neigiami }\end{array}$ & $\mathrm{Ne}$ \\
\hline
\end{tabular}

tihistamininių preparatų, o užsitęsus patinimui - $50 \mathrm{mg}$ prednizolono kelias dienas. Prasidejus sisteminei anafilaksinei reakcijai, gydoma simpatikomimetiniais, H1 antihistamininiais vaistais ir gliukokortikoidais.

2 paveiksle pateikiamas anafilaksinių sisteminių reakcijuc pagalbos algoritmas.

Adrenalinas - svarbiausias vaistas, kurio turi būti skirta nedelsiant. Jis didina ląstelès cAMF kieki ir taip slopina mediatorių išsiskyrimą iš putliųjų ląstelių bei bazofilų. Be to, dèl jo poveikio beta adrenoreceptoriams atsipalaiduoja bronchų spazmas, dideja miokardo kontrakcija ir širdies susitraukimų dažnis. Veikdamas alfa adrenoreceptorius, didina arteriolių tonusą ir diastolinị kraujo spaudimą. Vaistas veikti pradeda greitai, bet poveikis trunka neilgai - apie 5 min. Anafilaksijos metu skiriamas injekcijomis i poodi, raumenis, veną bei infuzijos būdu. Injekcijomis i poodị bei i raumenis (i r r.) vartojamas neskiestas adrenalino tirpalas 1:1000 (0,1 proc.) sušvirkščiant $0,3-0,5 \mathrm{ml}(0,3-0,5 \mathrm{mg})$, vaikams - 0,01 $\mathrm{mg} / \mathrm{kg}$. Esant reikalui, injekciją galima kartoti kas 5-10 min. 2 ar 3 kartus. Injekcijomis ị veną (i v.) vartojamas 10 kartu praskiestas $\mathrm{NaCl} 0,9$ proc. tirpalu adrenalino tirpalas 1:10000 (0,01 proc.). Taip praskiesto adrenalino tirpalo $1 \mathrm{ml}$ yra $0,01 \mathrm{mg}$ adrenalino. Švirkščiama $1-2$ ar net $3 \mathrm{ml}$, vaikui - 0,01-0,05 $\mathrm{ml} / \mathrm{kg}(0,01 \mathrm{mg} / \mathrm{kg})$; sušvirkščiama ne greičiau kaip per 3-5 min.

Infuzijai $1 \mathrm{ml}$ 1:1000 adrenalino praskiedžiamas $250 \mathrm{ml}(1 \mathrm{ml}$ bus $0,002 \mathrm{mg}$ arba $2 \mu \mathrm{g}$ adrenalino $) \mathrm{NaCl}$ 0,9 proc. tirpalo Lašinama nuo $1-4 \mu \mathrm{g}$ per minutę, vaikams $-0,1-1,0 \mu \mathrm{g} / \mathrm{kg}$ per minutę. 


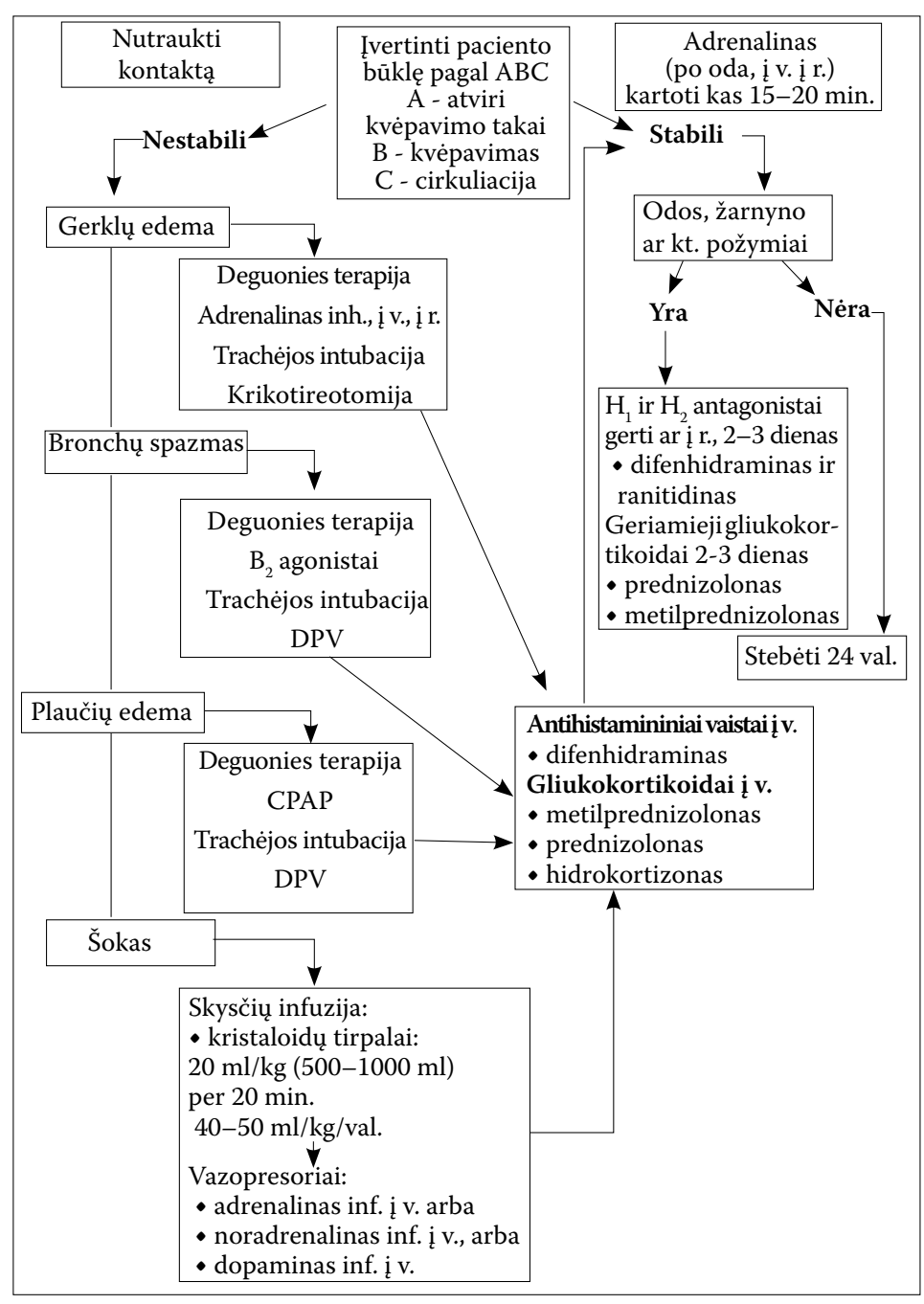

2 pav. Pagalbos ištikus anafilaksijai algoritmas [10]

Nepageidaujamas adrenalino poveikis dažnesnis, kai greitai $\mathfrak{i}$ veną suleidžiama didelè jos dozè: tai aritmijos, vainikinių arterijų spazmas, miokardo infarktas, respiracinis distresas, kraujavimas ị smegenis. Vis dèlto netgi sergantiesiems širdies ir smegenų kraujagyslių ligomis adrenalino nauda anafilaksijos metu pranoksta galimą nepageidaujamo poveikio žalą.

\section{SPECIFINÉ IMUNOTERAPIJA}

Specifine imunoterapija plèviasparnių būrio (Hymenoptera) vabzdžių nuodų alergenais gydomi pacientai, kurie patyrè imunoglobulino E (IgE) sukeltą išplitusią alerginę reakciją igèlus vabzdžiui.

Specifinė imunoterapija vabzdžių nuodų alergenais yra vienintelis gydymo būdas, galintis sumažinti pakartotinès anafilaksijos tikimybę nuo 75 iki mažiau nei 5 proc. Irodyta, kad po sėkmingos imunoterapijos kraujyje padaugèja blokuojančių IgG4 klasès antikūnų, susidaro IgE gamybą moduliuojančių CD4+ T limfocitų, sumažèja mediatorių išskyrimas iš putliųjų ląstelių, bazofilų. Irodyta, kad imunoterapijos metu alergenui specifiniai T limfocitai tampa anergiški dèl padidèjusios IL 10 sekrecijos iš reguliuojančių T limfocituc CD4+CD25+.

Specifinès imunoterapijos taikyti negalima, kai pacientas serga sunkiomis gretutinėmis širdies, kepenų, inkstų ligomis, lètinėmis infekcijomis, autoimuninėmis ligomis, kraujo piktybinėmis ligomis, vartoja beta adrenoblokatorių (jei nutraukus jų vartojimą, pavojus širdies ir kraujagyslių sistemai didesnis už keliamą anafilaksijos, specifinè imunoterapija netaikoma, o jei dideli abu pavojai - nenutraukti beta adrenoblokatorių ir specifinę imunoterapiją taikyti stebint arterinị kraujo spaudimą ir EKG). Specifinè imunoterapija nepradedama ir néštumo metu, o palaikomasis gydymas tęsiamas.

Itin skubus specifinès imunoterapijos protokolas, kai $100 \mu \mathrm{g}$ nuodų alergenų palaikomoji dozè pasiekiama mažiau negu per 6 val., pagreitina apsauginį specifinès imunoterapijos poveikị, sumažina nepageidaujamų reakcijų tikimybę ir yra patogus pacientui, tačiau taikomas stacionare $[6,7]$. Indikacijos taikyti specifinę imunoterapiją pateikiamos 2 lentelëje.

Palaikomosios alergenų vakcinos dozès leidžiamos ambulatoriškai kas keturias savaites pirmuosius metus, po to - kas šešias savaites ir tęsiamos 3-5 metus ar ilgiau. Specifinè imunoterapija skatina vabzdžių nuodų alergenų toleravimą, bet gali sukelti nepageidaujamų reakcijų, kurios dažnesnes gydant bičių nuodų alergenais, moterims ir didinant vakcinos dozę. Daugiacentrio tyrimo duomenimis, 20 proc. imunoterapiniais vaistais gydytų pacientų patyrė sisteminių reakcijų [8].

\section{HYPENOPTERA VENOM ALLERGY: DIAGNOSIS, EMERGENCY TREATMENT AND SPECIFIC IMMUNOTHERAPY}

\author{
EDITA GASIÜNIENÉ, JÜRATÉ STAIKÜNIENÉ \\ DEPARTMENT OF PULMONOLOGY AND IMMUNOLOGY \\ LITHUANIAN UNIVERSITY OF HEALTH SCIENCES
}

Keywords: insect sting, Hymenoptera, anaphylaxis, specific immunotherapy. Summary. Hymenoptera venom allergy is most often caused by stings of the honeybee and the wasp. The most frequent clinical patterns are the large local reactions and generalized immediate type allergic reactions such as urticaria, angioedema, anaphylaxis. The diagnosis of Hymenoptera venom is based on a history, clinical symptoms, positive skin tests and the presence of venomspecific lgE serum antibodies to the respective venom. Venom immunotherapy lasting three to five years is estimated to decrease the risk of venom-related anaphylaxis rate of $75 \%$ to less than $5 \%$.

\section{LITERATŪRA}

1. Staikūnienė J. Vabzdžių igèlimo sukeltos alerginès reakcijos. Lietuvos bendrosios praktikos gydytojas 2010, tomas XIV, Nr.4.

2. Pumphrey RS. Lessons for management of anaphylaxis from study of fatal reactions. Clin Exp Allergy 2000; 30 (8): 1140-50.

3. Moffitt JE, Golden DB, Reisman RE, Lee R, Nicklas R, Freeman T et al. Stinging insect hypersensityvity: a practice parametre update. J Allergy Clin Immunology 2004; 114 (4): 869 - 886

4. Muller U, Mosbech H. Position paper: immunotherapy with hymenopters venoms, Allergy 1993; 48; $37-46$.

5. Bonifazi F, Jutel $M$, Bilo MB, Birnbaum J, Muller $U$ et al. EAACl position paper.

6. Muller U, Johansen N, Petersen AB, Fromberg - Nielsen J at al. Hymenop-

tera venom allergy: anglysis of dumble positivity to honey bee and Vespula venom by estimation of $\mathrm{Ig} E$ antibodies to specines-specific major allergens Api m1 and Ves v5. 2009; 64 (4) 543-550

7. Wysii M, Scheitlin T, Stadler BM, Wuthrich B. Immunotherapy with aluminum hydroxide adsorbed insect venom extracts:imunologic and clinical results of a prospective study over 3 years. Allergy 1993; 48 (1)81-89

8. Mellerup MT, Hahn GW, Poulsen LK, Malling HJ. Safety of allergen specific immunotherapy. 2000, 1423-1456

9. Mosbech $\mathrm{H}$, Muller U. Side - effects of insect venom immunotherapy: results from an EAACI multicenter study. Allergy 2000(11) 1005

10. Anafilaksija. Metodinès rekomendacijos, Vilnius, 2002. 5. 